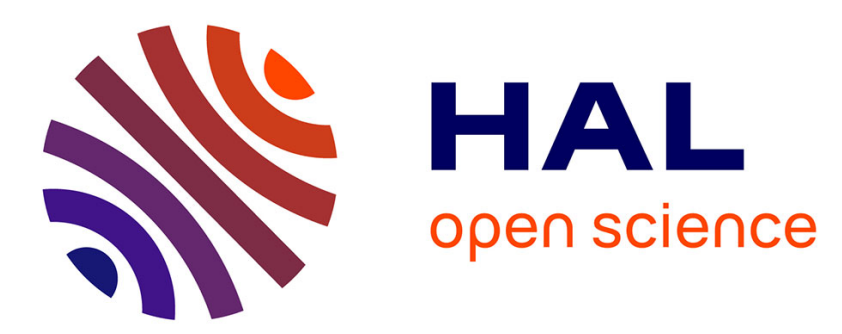

\title{
Structuring and evolution of the winegrowing groups of Champagne: a first study
}

Pascale Lambert, Jean-Paul Méreaux

\section{To cite this version:}

Pascale Lambert, Jean-Paul Méreaux. Structuring and evolution of the winegrowing groups of Champagne: a first study. Colloque de Bologne en Italie - 2017, Jun 2017, Bologne, Italy. hal-02571455

\section{HAL Id: hal-02571455 \\ https://hal.univ-reims.fr/hal-02571455}

Submitted on 12 May 2020

HAL is a multi-disciplinary open access archive for the deposit and dissemination of scientific research documents, whether they are published or not. The documents may come from teaching and research institutions in France or abroad, or from public or private research centers.
L'archive ouverte pluridisciplinaire HAL, est destinée au dépôt et à la diffusion de documents scientifiques de niveau recherche, publiés ou non, émanant des établissements d'enseignement et de recherche français ou étrangers, des laboratoires publics ou privés. 


\title{
Structuring and evolution of the winegrowing groups of Champagne: a first study
}

\section{Pascale LAMBERT, Jean-Paul MÉREAUX}

\author{
University of Reims Champagne-Ardenne, France \\ Pascale.lambert@etudiant.univ.reims.fr jp.mereaux@univ-reims.fr
}

\section{Introduction}

Structuring, by definition, is the action of structuring, acquiring a structure. Many authors have proposed definitions of structuring and thus contributed to construct a theory of structuring. Thus, Giddens (1987) shows how society can be constituted and structured with the movement of actors, Autissier and Wacheux (2000) define the theory of structuring as "a metatheory of action"; Whittington (1992) as a "macro-social metatheory". For Rojot (2012), the theory of structuring is mainly used in the social sciences and has direct interests and applications in management sciences but more in a political context.

Finally, according to Husser (2010), "the theory of structuring instructs the field of management sciences in a pertinent way because it proposes an innovative prism focusing in particular on organizational processes". Moreover, for Husser, the theory of structuring allows "to advance explanations relating to organizational change". It invites us to reflect on how companies have structured themselves over time under the influence of various internal and external factors. These contingency factors, such as environmental complexity, technical system, differentiation-integration, have been demonstrated by many authors (Burns and Stalker, 1963, Woodward, 1965, Lawrence et al. Lorsch, 1973). As a follow-up to this work, Mintzberg (1990) proposes an analysis of the different elements composing an organizational system by distinguishing between six different structural configurations.

Applied to the wine sector in Champagne, these theoretical reading grids lead us to reflect on the way in which companies in this sector have been structured over time, especially with the emergence of groups. The notion of group in this sector of activity has taken very different forms: classic with the grouping of companies or hybrid with the creation of cooperatives; Groups or publicly traded groups. However, regardless of the legal form taken by these winegrowing groups in Champagne, their construction and evolution have led, as in any organization, to upheavals (Thietart, 1982). This approach, linked to the evolution of organizations, was emphasized historically by Chandler (1962) as Seiffert (2008) points out. It induces organizational changes (VandangeonDerumez, 2007). 
Indeed, as Greiner $(1972,1998)$ shows, a company goes through different stages of growth (creation, direction, delegation, coordination, collaboration, extra-organizational) that are key steps in change and can Be sources of organizational turbulence (Evrard, 2003).

It is therefore necessary to consider the adjustments made in terms of structuring according to the different stages of development of these wineproducing wine-producing enterprises in the Champagne region, which led them to create groups. Are these approaches consistent? What are its characteristics? By opting for extra-organizational growth through acquisitions or when the development of their activities is realized by the creation of more atypical groups such as cooperative unions that induce different management as a result of its hybrid character (Ménard, 1997), Impacts are not neutral on the organizational structure and constitute an interesting path in terms of research in order to identify the determinants and characteristics of the passage from one stage to another. It is in this context that we have chosen to focus on the notion of structure, before considering the changes that they can undergo. Finally, we will close this communication by studying a listed winegrowing group.

\section{FROM THE CONCEPT OF STRUCTURING TO THE CONCEPT OF STRUCTURAL CONFIGURATIONS}

\subsection{The notion of structuring, a necessary definition}

First, it is necessary to consider the various meanings that the term "structure" may have. It can be seen as the way in which companies and groups in the wine sector have structured themselves. Of course, one may be led to think of a legal definition, but this concept can not be reduced to this single field. Indeed, this only acceptance seems to be reductive and insufficient, even if the Champagne groups in the wine sector began to structure themselves differently during the 1960s (in 1966, the law on capital companies The law of July 24, 1966, from which the mergers and acquisitions carried out by public limited companies).

The term structure can be understood in the economic sense, Williamson which distinguishes the firm from the organization (1985) and echo the various structural configurations specific to companies.

Thus, the concept of structure resonates both in organizational theory with Mintzberg (1982) for the structural configuration approach, and in management with Desreumaux, (1992) who distinguished between the various forms of structure Enterprises and also in corporate strategy such as Chandler (1962, 1972).

The definition of the concept of structure is pluralistic, because of an abundant literature. Thus, according to Desreumaux (1992), "the structure encompasses all the mechanisms and mechanisms by which an organization 
divides, distributes, coordinates, controls its activities into tasks and, beyond that, directs or attempts to direct and control the behaviors of Its members according to its purposes ". For Mintzberg (1990), the structure of an organization is the sum total of the means used to divide the work into separate tasks and then to ensure the necessary coordination between these tasks.

Finally, according to Crozier and Friedberg (1977), the formal structure is the provisional codification of a state of equilibrium between the power strategies involved.

These definitions point to different points, the structure has a role to coordinate, to distribute activities, which are then divided into tasks. Finally, it outlines the powers of the various actors to establish power strategies. This means that the structure would have two roles: to coordinate activities, then tasks to achieve an end, and to stimulate the players involved in order to take advantage of power.

In view of these elements, one could thus make a first link between the structure and the strategies of the actors with a view to capturing power. Which would mean that within the structures, power manifests itself but in different ways. It is here that the distinction between the various forms of structures taken by companies, and taken up by Desreumaux (1992), namely, the functional structure, the divisional structure, the matrix structure, and finally the structure by project and that in Network demonstrates a different decision-making and a transmission of power that is equally so.

In order to synthesize, the structure thus makes it possible to coordinate activities and then tasks in order to achieve common objectives, objectives linked to the same purpose that the latter is economic or societal. Finally, the structure can also be used to regulate conflicts, oppositions between actors, to create cooperation between people; It is the choice of the structure of the company that can act on one or the other of the possibilities

\subsection{Structural configurations}

\subsubsection{A Contingent Approach}

Finally, the choice of the type of structure should also be considered. Choice, which, moreover, is done according to different elements, called also factors of contingency. Indeed, the structures of the winegrowing groups of Champagne, champagne houses are dependent on factors like all businesses. These elements make a real reference to the theory of organizations, the link between structure and strategy, but also the relationship with the size of the company, the relationship with the environment, and finally the link between structure and technology. 
It was A. Chandler who first highlighted the link between structure and strategy, so "every time the strategy is changed, there is a change in the structure of firms". At the end of these research results, the author highlights two types of structure, the "U" shape for a structure organized into functional departments, and finally the "M" shape for a divisional structure.

The research carried out by Blau (1970) and Blau and Schoenherr (1971) have highlighted the fact that the increase in the size of a company encourages managers to adopt a structural change in order to coordinate At best the activities and tasks of each, as we explained during the first managerial definitions of the structures.

Finally, the link between structure and technology was established by Joan Woodward in 1958, the author showed that the choice of structures observed was a function of the type of technology used.

Another decisive factor in the choice is the evolution of the structure of a company, that of the environment. In 1961, T. Burns and G.M. Stalker showed the different organizational situations of firms according to the type of environment in which they were located. Thus, companies in a certain environment where information reaches them easily and without particular constraints, there are mechanistic and organic structures. On the contrary, when firms are in an uncertain environment, where there is some instability, the authors have observed an organic structure in which the organization is more flexible.

Ithough the environment has an influence on the structure that the organization can adopt, the latter is integrated by the organization within its structure in such a way that it can be differentiated (Lawrence and Lorsch, 1973). The determinants of the structure are external, it is questionable whether other variables can also affect the choice of structure.

\subsubsection{The contingencies of the wine sector}

First, with regard to the environment, the legal constraints posed by the State and the corresponding social administrations can also exert pressure and push to other types of structures. The winegrowing groups and the Champagne Houses evolve in a legal environment as regards the delimitation of the territory granted for the grape varieties, as regards the method of fixing the price of the grape, as regards the attributions of the various appellations of wines such as first cru, big cru ... This means that, besides, the links with technology, environment, size, strategy; The role of the State can also be preponderant.

Moreover, the structure of an enterprise can also depend on the will of the manager (G. Charreaux, 1996), his personality, or even the strategic choices he may have to make for his company. It would seem, therefore, that various factors internal and external to any enterprise can be studied and measured. 
The wine sector is specific by the various structures it understands, and the different actors that coexist. It also sets up partnership actions between structures, as highlighted in a group of wine cellars by Boutary, Monnoyer et al (2012). It also sees the concentration of large wine-producing firms (Coelho, 2013).

\section{BUSINESS STRUCTURING AND DEVELOPMENT: BETWEEN DEPENDENCIES AND INTERDEPENDENCIES}

Development by definition is the act of growing, growing, and developing. In economics, it is a qualitative improvement in the functioning of an organization. In this, development is akin to the concept of growth. Growth that uses different modalities such as organic growth or internal growth (the organization grows by its own resources), external growth, and finally growth through alliances. On the other hand, the development of organizations and, in the case of wine-growers in Champagne, depends on general contingency factors and more specific factors.

The concept of development can also be understood as the notion of cycle, stages, phases, in the sense of Greiner (1972 and 1998), but also earlier, such as the works of Scott (1967) and Lippitt \& Schmidt (1967). Finally, this model has been taken up by many researchers (Peiser $\&$ Wooten, 1983, Churchill \& Lewis, 1983, Tushmann, 1983, Mel Scott \& R. Bruce, 1987). According to Greiner, the concept of change, evolution takes place in phases, in stages, the latter are also five and all correspond to very specific criteria (see Table 1). At first sight, it appears that this evolution is linear, and seems to depend on the structure and contingency factors, but we will see that the phase of extra-organizational growth challenges this foundation.

\subsection{A more classic, even linear evolution}

The term evolution suggests the idea of changes, only this notion of change can be studied in relation to a temporal basis. Indeed, evolution can be understood and seen in the long term as the notion of upheaval. Thus, concerning the wine-growing sector in Champagne, it is interesting to look at the changes that have occurred, the groups that have been built, or even created, or those that have disappeared. All of these changes for the wine sector can be the result of a manager (Charreaux, 1996). Indeed, the objective of the leaders of the wine sector could be the desire to see a control exercised and preserved by champagne families, or else the desire to preserve a regional or even local heritage to preserve an identity (Soenen and Moingeon 2002, 2008).

However, the manifest will of leadership, the impact of exogenous elements, such as financial crises on companies. To this end, this suggests more cyclical instability (Azan, 2007). Finally, these crises induce a change in firms that occurs in stages until companies have adapted to the changes caused by the environment, Lawrence and Lorsch (1994). It can also induce selection on the 
routines of firms, requiring them to modify, adapt their tacit knowledge (Nelson and Winter, 1982). This would make a selection on the companies, and therefore, on the structure.

Although the Champagne sector is an artisanal activity, it can be considered as a network with customers, suppliers (Chanut \& Poirel, 2012), insofar as different actors are linked, which can lead to the idea Governance (Ehlinger et al., 2007). Finally, the latter sometimes behave like companies when they organize themselves beyond their borders - as Coelho pointed out in 2013 -. In addition, Act No. 92-643 of 13 July 1992 allows cooperative societies to contribute external capital.

However, we must not neglect the temporal basis which begins from the sixties, if we admit, that the law of January 6, 1966 relating to the formation of the "Société Anonyme" and "Société à Responsabilité Limitée".

The combination of the Greiner model with a Chandlerian historical approach and more recently that of Seiffert (2008) makes it possible to justify, to account for the evolution of firms, their development in a historical way At least for a first reading. This model of entrepreneurial growth specifies the successive stages of business growth. There are five stages: growth through creativity, growth by management, then by delegation, and finally by coordination and collaboration.

\section{Growth through creativity}

It is an entrepreneurial management, the company is in gestation, the structural configuration is of a "primitive" simplicity. The company is very marked by the leadership of the creator, true man-orchestra. Communication is informal, work is hard and labor income is still insufficient. The company will emancipate itself from its creator to reach the next stage of growth.

\section{Growth by management}

The company adopts a functional structure (a specialization of skills), business is structured with the implementation of accounting, capital management, seeking profitability. The structure begins to develop, to be hierarchized, but the company remains marked by its creator and the corporate culture in the image of the creator. This growth ends with a crisis of autonomy.

\section{Growth by delegation}

The crisis of autonomy necessarily involves the need to decentralize certain decisions. The structure is decentralized, the different operational and commercial levels are put in place. However, the beginnings of a new internal growth crisis are emerging. Indeed, the various decentralized functions demand 
legitimacy and maintain a relationship with the company (Jensen and Meckling, 1976), not a private law relationship.

\section{Growth through coordination}

Different families of products are set up, the company begins to carry out investment expenses abroad. Finally, the functions of the supports are centralized. This structural configuration allows, with the implementation of management tools, to overcome this internal crisis and to evolve towards coordination. The business continues to grow, and management tools are upgrading. The risk is looming with the crisis of a bureaucracy.

\section{Collaborative growth}

Collaboration is expressed through the establishment of inter-functional task-oriented teams. The organization is matrix. This evolution of the structural configuration makes it possible to overcome the losses of inertias. The setting up of cross-functional teams on short-term business projects allows the company to regain dynamism and a motivated team. However, some teams may seek to emancipate themselves;

\begin{tabular}{|c|c|c|c|c|c|}
\hline & $\begin{array}{l}\text { ORGA } \\
\text { IN THE }\end{array}$ & $\begin{array}{l}\text { NIZATIO } \\
\text { FIVE PH }\end{array}$ & $\begin{array}{l}\text { AL PRAC } \\
\text { ES OF G }\end{array}$ & $\begin{array}{l}\text { TICES } \\
\text { ROWTH }\end{array}$ & \\
\hline CATEGORY & PHASE 1 & PHASE 2 & | PHASE 3 & PHASE 4 & PHASE 5 \\
\hline $\begin{array}{l}\text { Mansgement } \\
\text { focus }\end{array}$ & Make and sell & $\begin{array}{l}\text { Efficiency of } \\
\text { operations }\end{array}$ & $\begin{array}{l}\text { Expansion of } \\
\text { market }\end{array}$ & $\begin{array}{l}\text { Consolidation of } \\
\text { organization }\end{array}$ & $\begin{array}{l}\text { Problem solving } \\
\text { and innovation }\end{array}$ \\
\hline $\begin{array}{l}\text { Organizational } \\
\text { Structure }\end{array}$ & Informal & $\begin{array}{l}\text { Centralized and } \\
\text { functional }\end{array}$ & $\begin{array}{l}\text { Decentralized } \\
\text { and grographical }\end{array}$ & $\begin{array}{l}\text { Line staff and } \\
\text { product groups }\end{array}$ & Matiix of tesms \\
\hline $\begin{array}{l}\text { Top-Management } \\
\text { Style }\end{array}$ & $\begin{array}{l}\text { Individualistic and } \\
\text { entrepreneurial }\end{array}$ & Directive & Delegative & Watchdog & Participative \\
\hline Control System & Market results & $\begin{array}{l}\text { Standards and } \\
\text { cost centers }\end{array}$ & $\begin{array}{l}\text { Repports and profit } \\
\text { centers }\end{array}$ & $\begin{array}{l}\text { Plans and invest- } \\
\text { ment centers }\end{array}$ & $\begin{array}{l}\text { Mutual goal } \\
\text { setting }\end{array}$ \\
\hline $\begin{array}{l}\text { Management } \\
\text { Reward Emphasis }\end{array}$ & Ownership & $\begin{array}{l}\text { Salary and merit } \\
\text { increases }\end{array}$ & Individual bonus & $\begin{array}{l}\text { Profit sharing and } \\
\text { stock options }\end{array}$ & Team bonus \\
\hline
\end{tabular}

Table 1: Characteristics of growth phases according to Greiner (1998) 


\subsection{A structuring, a development that is interdependent}

The Greiner model sees an extension with the emphasis on extraorganizational growth, comprising two stages (S. Evrard, 2000). This growth uses the tools of external growth, and those of growth through alliances through cooperative agreements (alliances and partnerships). The new structural configuration is presented in particular by the network firm (Chanut \& Poirel, 2012) and the notion of extended enterprise insofar as the company learns from others (Benchimol, 1993; Grundstein, 2003).

It includes a first step known as the "transitional" stage during which the companies that have been the subject of a buy-back or a merger still retain some of their autonomy. Then, the second step called "integration" corresponds to the fact that the newly acquired firm is integrated into the structure flowchart (see Figure 2).

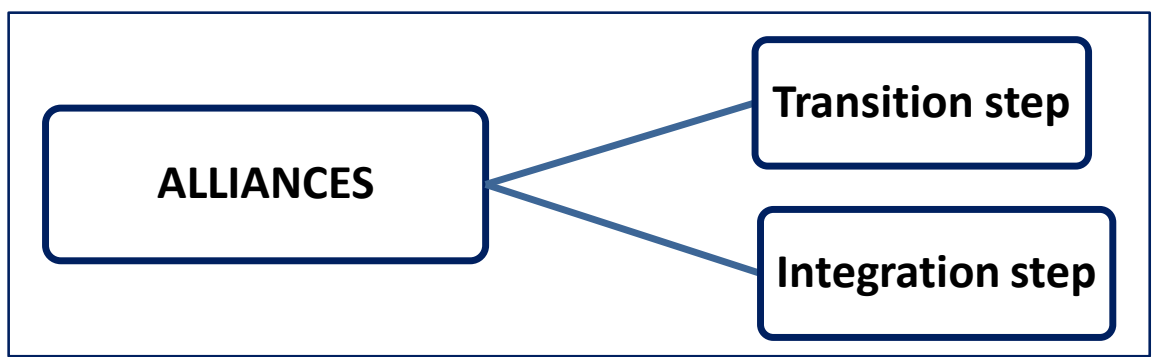

Figure 1: The decomposition of the alliances growth phase (Evrard-Samuel, 2000)

The originality is to perform a Greinerian reading of a quoted group according to sources collected - with a Chandlerian perspective. Indeed, a listed group represents an essential interest, that of easily collecting official publications such as reference documents, sales reports.

Greiner's model will be used as a theoretical frame of reference to show that the structuring of the Champagne Houses groups has evolved over time since the second half of the twentieth century. The challenge is to show that the evolution of the structuring of the LVMH group does not always follow any logic or opportunistic choices of leaders, but can be a cyclical evolution such as that of the Greiner model.

The use of this model will make it possible to verify, from official sources, the degree of evolution of the group. Finally, it can make it possible to highlight, the existence of a Greinerien model specific to the wine-growing sector champagne. Indeed, this model mainly predictive, and, little used in the francophone works can be rehabilitated for the wine industry champagne. However, this model may seem simplistic but in reality the application is more 
complex than it seems. In addition, the use of the Greiner model is interesting for - at least - two reasons. It is innovative because it highlights five phases, all of which culminate in an internal growth crisis.

Finally, the demonstration of the so-called "extra-organizational" phase brings an additional and major interest to the Greiner model. This makes it possible to understand, the reasons that in the past have been able to encourage group formation. The model does not show a continuous organizational change as suggested (Vandangeon-Derumez, 2007). However, it is a primarily descriptive model which must then be supplemented by interpretations.*

The use of the model and work of Evrard-Samuel (2000) is coupled with a Chandlerian study to show whether the phases as described by Greiner (1972, 1998) prove to be so linear. The complexity stems from the fact that the LVMH group was formed over a period of five decades. Moreover, the complexity comes from the fact that we want to show an evolution that traces that of the different houses that built the LVMH group.

\subsection{CONSTITUTION AND DEVELOPMENT OF THE CHAMPENOIS VITI-VINICOL GROUPS: A FIRST ANALYSIS}

\subsection{Methodology}

The method of investigation used is called mixed (Miles and Huberman, 2005). First of all, we favor a qualitative approach in order to verify the legal existence of the various Houses composing it and their links with the group. In this respect, the investigation is carried out using the LVMH website, from which a report on activities was collected for the period 2005-2013. We have chosen an analysis of the financial documents, and have cross-checked the information with the histories of the various houses integrated in the LVMH group.

Then, we made a synoptic sheet of the group studied and we favored a comparative approach. This method consists of comparing the periods studied, that of the years 1969-2000 and the period 2005-2012. Although the turnover is available over five years, the reference period for this research is 2005-2012. After a quick presentation of the group, it is a question of analyzing successive periods in order to observe if there is a break, or on the contrary a continuation of the logics of groups.

\subsection{Presentation of the LVMH Group}

The group was born of the merger between two companies Louis Vuitton and Moët Hennessy. The name of the LVMH group represents the juxtaposition of the initials of the two companies. At the outset, the group was formed as a public limited company (société anonyme), a legal structure that allowed it to buy back 
various Champagne Houses such as Eugène Mercier, Ruinart Champagne, Krug House and, Finally, Veuve Clicquot.

During the years 2005-2016, the LVMH group at the level of the Champagne branch seems to have stabilized, the various houses are perfectly integrated into the group. The history of the group makes it a group of listed champagne houses that was until 2001, the first group in bottle shipments. The LVMH group is currently pursuing an internationalization strategy and has taken the status of a European company since 27 October 2014.

\subsection{Results and discussions}

We present in the appendix the results concerning the structuring of the LVMH group based on Greiner's (1998) five-phase growth model. Then, we show the complexity of the "extra-organizational" phase proper to Evrard-Samuel (2000).

We note that it was from 1728, that the exports of Champagne were intensified, thanks to the royal decree made in the same year, by King Louis XV, which makes it possible to affirm, that the role of the state is an external determinant contingency factor.

It is as early as the 19th century that the first "Millésimés" are elaborated, which makes it possible to specify that groups of products are emerging, from this period, companies begin to specialize, their structure must adapt in order to manage Different product lines.

The company Moët \& Chandon was the instigator of the creation of the LVMH group, thanks to the first rapprochements carried out in 1962 and especially under the direction of Robert Jean de Vogue. The personality of the leader seems to have been decisive (Charreaux) and Hirigoyen (2009), in the construction of the group, as it exists today, this element seems to be confirmed. The creative phase of the LVMH group originated in the early 1960s when the widowed Clicquot Ponsardin adopted the statutes of a public limited company and began with an opening of its capital on the stock exchange.

The year 1987, marks the integration of different houses absorbed by the LVMH group. This second stage of "integration" continues until today.

The so-called growth phases by direction, delegation, coordination and control seem to be accelerated or even confused because of the speed between the initial IPO for each of the master groups that make up LVMH; And the legal birth of the LVMH group. The phase of growth by collaboration seems to be the reflection for the holding Veuve Clicquot Ponsardin and the Moët-Hennessy group of the personality of a leader. 
Finally, the means of organic growth were used until the early 1960s, so it can be said that the tools of organic growth are mainly used during the phases of the Greinerien model. Referring to the work of Evrard Samuel (2000) on the extraorganizational phase, the LVMH group began around 1962 and continues until today. However, it includes a first stage called the "transitional phase", which began in the early 1960s when the IPO was launched.

Beginning in 1966, the group underwent growth through acquisitions, followed by acquisitions and mergers. The sixth phase of growth appears to be more complex and involves many stages. Thus, for the LVMH group, there is a juxtaposition of two "extra-organizational growth phases" for each of the constituent groups of the group, namely Louis-Vuitton and Moët Hennessy. These elements allow us to specify that this final phase represents a key period in the structuring of the companies in the sector, and that they are experiencing major changes both in their structuring and in their development (Thiétart, 1982). These seem to be interdependent with other phases (S. Evrard Samuel, 2000).

\section{Conclusion}

Our work has shown that the LVMH group has favored internal growth initially and that the opening of capital has led to a shift towards external growth. The use of extra-organizational solutions took place in two stages, passing through a transitional stage in order to allow the integration of companies in the group.

It would be interesting to look at another winegrowing group in order to check whether the acceleration of the growth phases 1 to 5 of the Greiner model is also verified and, under the impetus of which contingency factors.

The collected data must be sufficient in number to show the different phases of growth in detail. These data coupled with an exploratory research could make it possible to show concretely the characteristic elements specific to the Greiner model. This could also fill in the gaps revealed by this research.

Indeed, growth phases have been left in abeyance due to missing information. Finally, reading can not reveal the different crises of the different groups studied. This justifies a qualitative method for exploratory purposes that could be either mono-site or multi-site for future work (Miles and Huberman, 2005).

\section{References}

Azan W. (2007). Développement chez F. Perroux et performance par le changement organisationnel. Revue française de gestion, (2), 15-30.

Benchimol G. (1993), « L'entreprise étendue», Hermès, Coll. Systèmes d'information.

Blau P.M. (1970), " A formal theory of differenciation in organizations », American Sociological Review, vol. $32 \mathrm{n}^{\circ} 2$, p. 201-218. 
Blau P.M., Schoenherr (1970), « The structure of Organizations, New York, Basic Book 1971. "

Boutary M., Faure R. \& Monnoyer, M. C. (2012). PME et groupements: antinomie définitive ou nouvelle nécessité?. La Revue des Sciences de Gestion, (5), 101-109. Burns, Stalker (1966), « The management of innovation, Tavistock Publications, 2ème édition, Social Sciences Paperbacks.

Chandler A. (1972), "Strategy and Structure, MIT » press, Boston, 1962. Trad. Fr, Stratégies et structures de l'entreprise, Paris, Editions d'Organisation, 1972.

Chanut O., Poirel C. (2012). Quand les organisations en réseau réagissent collectivement face à la crise. Revue française de gestion, (4), 105-122.

Charreaux G, (1996) «Pour une veritable théorie de la latitude managériale et du gouvernement des entreprises » Revue Française de Gestion ( $\left.n^{\circ} 111\right)$ réimprimé RFG, $2015 / 8 n^{\circ} 253$.

Chuchill N.C., Lewis V.L. (1983), "The Five Stages of Small Business Growth », Harvard Business Review, $N^{\circ} 61$ (3), pages 30-39.

Coelho (2013) « concentration des grandes firmes vitivinicoles ».

Crozier M., Friedberg E. (1977), « L'acteur et le système », Paris, Le Seuil.

Desreumaux A. (1992), "Structures d'entreprise : reprises ? ", Analyse et gestion », Paris, Vuibert.

Evrard Samuel K. (2000), « Prise de contrôle et gestion de crise : une analyse par les processus ", Actes du congrès ASAC-IFSAM, Montréal, Québec, Canada

Desreumaux A. (1981). Histoire et structure des entreprises. Revue Française de Gestion, (32), 87-97.

Gareis R. (2010), " Changes of organizations by projects », International Journal of Project Management. Volume 28, pages 314-327.

Giddens A. (1987), « La constitution de la société, éléments de la théorie de la structuration » PUF, Collection sociologie, Paris, 474 pages.

Greiner L.E. (1972), " Evolution and revolution as organizations grow », Harvard Business Review, July-August 1972, pages 37-46.

Greiner L.E. (1998), « Evolution and revolution as organizations grow», Harvard Business Review, May-June, pages 1-11.

Grundstein, M. (2013), " De la capitalisation des connaissances au management des connaissances dans l'entreprise », Les fondamentaux du knowledge management.

Hirigoyen G. (2010). Concilier finance et management dans les entreprises familiales. Revue française de gestion, (8), 393-411.

Husser J. (2009), « La théorie de la structuration : quel éclairage pour le contrôle des organisations ? ॥, Vie \& sciences de l'entreprise, $n^{\circ} 183-184$, p. 33-55. 
Jaunet P., Paguet J.M. (2009), « Pour une analyse dynamique du lien structure/management ", Economie et Management, Octobre, n¹3, pages 5-13. Lippitt G.L., Schmidt W.H. (1967), « Crisis in developing organizations », Harvard Business Review, novembre - décembre.

Macpherson A. (2005), "Learning how to Grow: Resolving the crisis of knowing ", Technovation, issue 10, Octobre, pages 1129-1140.

Ménard C, (1997), "Le pilotage des formes organisationnelles hybrides ", Revue économique, 1997, volume 48, $n^{\circ} 3$, pp 741-750.

Miles B.M., Huberman A.M. (2005), « Analyse des données qualitatives », De Boeck.

Mintzberg H. (2004), " Le management, voyage au centre des organisations ». Editions d'organisation.

Mintzberg H (1982), « Structure et dynamique des organisations », Paris, Editions d'organisation.

Nielsen E.H. (1978), " The Human Side of Growth », Organizational Dynamics, Summer, pages 61-80.

Peiser R.B., Leland M. Wooten (1983), « Life-Cycle Changes in Small Family Businesses », Business Horizons, Mai-Juin, pages 58-65.

Scott M., Bruce R. (1987), « Five Stages of Growth in Small Business », Long Range Planning, Volume 20, $n^{\circ} 3$, pages 45-52.

Scott B.R. (1967), "Stages of corporate development », Harvard Business Review, Novembre - Décembre.

Soenen G., Moingeon B. (2003). «The five facets of collective identities ", Corporate and Organizational Identities, pages 13-34.

Soenen G., Moingeon B. (2008), « Identité organisationnelle, complexité et turbulence» in Ramanantsoa B. (dir.), L'art du management, Les Echos-Pearson, pp. 71-87.

Starbuck W.H. (1968), "Organizational Metamorphosis » in Promising Research Directions, edited by R.W. William and M.P. Hottenstein, Tempe, Arizona, Academy of Management.

Thiétart R.A. et coll. (2007), « Méthodes de recherche en Management ॥, Dunod, 4ème édition.

Wacheux F. (1996), " Méthodes qualitatives et recherche en gestion ", Economica.

Woodward J. (1958), " Management and Technology », HMSO.

Yin R.K. (1994), « Case Study Research », Sage Publications. 


\section{APPENDIX}

\begin{tabular}{|c|c|c|c|c|c|}
\hline Les phases & Moët et Chandon & Maison Ruinart & $\begin{array}{l}\text { Maison } \\
\text { Mercier }\end{array}$ & Veuve Clicquot & Maison Krug \\
\hline $\begin{array}{l}\text { (1) } \\
\text { Creativity }\end{array}$ & $\begin{array}{l}\text { As early as } 1743 \text {, the } \\
\text { House was created by } \\
\text { the founder. He will } \\
\text { keep the company } \\
\text { until } 1792\end{array}$ & $\begin{array}{l}\text { 1729: Year of } \\
\text { creation of the } \\
\text { Ruinart House, } \\
\text { it is also } \\
\text { dedicated to the } \\
\text { manufacture of } \\
\text { sheets }\end{array}$ & $\begin{array}{l}\text { 1858: Creation } \\
\text { of the House } \\
\text { Mercier. } \\
\text { The first } \\
\text { foundations } \\
\text { are thrown }\end{array}$ & $\begin{array}{l}\text { The first } \\
\text { foundations are } \\
\text { thrown 1772: } \\
\text { Year of creation. } \\
\text { The intentions } \\
\text { of the founder } \\
\text { are clear "cross } \\
\text { the borders of } \\
\text { the kingdom" }\end{array}$ & $\begin{array}{l}\text { 1843: } \\
\text { Creation of } \\
\text { the Krug } \\
\text { House by } \\
\text { Joseph Krug }\end{array}$ \\
\hline $\begin{array}{l}\text { (2) } \\
\text { Direction }\end{array}$ & $\begin{array}{l}\text { 1792, Jean Rémy Moët } \\
\text { took over the } \\
\text { management of the } \\
\text { company after his } \\
\text { grandfather. The } \\
\text { company will have a } \\
\text { new boom }\end{array}$ & $\begin{array}{l}\text { 1735: the House } \\
\text { chooses to } \\
\text { devote itself } \\
\text { solely to the } \\
\text { wine of } \\
\text { bubbles. The } \\
\text { company } \\
\text { chooses to } \\
\text { devote itself to } \\
\text { a single product }\end{array}$ & $\begin{array}{l}\text { 1871: The } \\
\text { company } \\
\text { takes a more } \\
\text { frank direction } \\
\text { towards the } \\
\text { production of } \\
\text { champagne. } \\
\text { The symbol is } \\
\text { the } \\
\text { construction } \\
\text { of the cellars } \\
\text { in Epernay }\end{array}$ & $\begin{array}{l}\text { 1805: The } \\
\text { House will take } \\
\text { a new direction } \\
\text { thanks to the } \\
\text { wife of the } \\
\text { founder who } \\
\text { kept the } \\
\text { business against } \\
\text { the advice of his } \\
\text { in-laws }\end{array}$ & \\
\hline $\begin{array}{l}\text { (3) } \\
\text { Delegation }\end{array}$ & $\begin{array}{l}\text { The company is } \\
\text { decentralized for } \\
\text { decision-making, } \\
\text { operational levels are } \\
\text { held accountable }\end{array}$ & $\begin{array}{l}\text { Operational } \\
\text { levels are } \\
\text { responsible } \\
\text { since the 1730s } \\
\text { with the export }\end{array}$ & & $\begin{array}{l}\text { 1773-1805: } \\
\text { These years } \\
\text { mark the rise } \\
\text { towards export }\end{array}$ & \\
\hline $\begin{array}{l}\text { (4) } \\
\text { Coordination } \\
\text { and } \\
\text { monitoring }\end{array}$ & $\begin{array}{l}\text { The first expeditions to } \\
\text { Europe and the other } \\
\text { countries of the world } \\
\text { give a new impetus to } \\
\text { the growth of the } \\
\text { company }\end{array}$ & $\begin{array}{l}\text { 1728: A royal } \\
\text { decree of } 25 \\
\text { May } 1728 \\
\text { authorizes the } \\
\text { transport of } \\
\text { wine in baskets } \\
\text { of } 50 \text { to } 100 \\
\text { bottles }\end{array}$ & & $\begin{array}{l}\text { 1810-1877: } \\
\text { Creation Of } \\
\text { groups of } \\
\text { products with } \\
\text { the 1st vintage } \\
\text { 1810; And the } \\
\text { remuage table } \\
\text { (1816) }\end{array}$ & \\
\hline
\end{tabular}




\begin{tabular}{|c|c|c|c|c|c|}
\hline $\begin{array}{l}\text { (5) } \\
\text { Collaboration }\end{array}$ & $\begin{array}{l}\text { In 1962, under the } \\
\text { control of Robert Jean } \\
\text { de Vogue, Moët and } \\
\text { Chandon looked for } \\
\text { new ways of evolving }\end{array}$ & $\begin{array}{l}\text { 1769: export } \\
\text { development } \\
\text { thanks to } \\
\text { wooden crates } \\
\text { adapted to } \\
\text { transport }\end{array}$ & & $\begin{array}{l}\text { 1909: Beginning } \\
\text { of the 20th } \\
\text { century, the } \\
\text { company was } \\
\text { looking for new } \\
\text { tracks }\end{array}$ & \\
\hline $\begin{array}{l}\text { ( } \\
\text { Alliances } \\
\text { (Transition } \\
\text { step) }\end{array}$ & $\begin{array}{l}\text { 1962: acquisition of } \\
\text { competitor Ruinart } \\
\text { 1970: Acquisition of } \\
\text { Maison Mercier } \\
\text { 1971: Acquisitions } \\
\text { outside the EU and the } \\
\text { world of wine with } \\
\text { Dior Parfums } \\
\text { 1971: The Moët- } \\
\text { Hennessy group was } \\
\text { born thanks to the } \\
\text { rapprochement with } \\
\text { the Cognac-Hennessy } \\
\text { house investment in } \\
\text { 1973: inver } \\
\text { California with the } \\
\text { launch of Domaine } \\
\text { Chandon in the Napa } \\
\text { Valley }\end{array}$ & $\begin{array}{l}\text { 1973: } \\
\text { investment in } \\
\text { California with } \\
\text { the launch of } \\
\text { Domaine } \\
\text { Chandon in the } \\
\text { Napa Valley } \\
\text { 1962: The } \\
\text { house was } \\
\text { bought by Moët } \\
\text { et Chandon }\end{array}$ & $\begin{array}{l}\text { 1962: Merger } \\
\text { with Moët \& } \\
\text { Chandon }\end{array}$ & $\begin{array}{l}\text { 1986: the House } \\
\text { is bought by the } \\
\text { Moët-Hennessy } \\
\text { group } \\
\text { cornerstone of } \\
\text { the future } \\
\text { group LVMH }\end{array}$ & \\
\hline $\begin{array}{l}\text { (6) } \\
\text { Alliances } \\
\text { (Integration } \\
\text { step) }\end{array}$ & $\begin{array}{l}\text { 1987: Merger of the } \\
\text { Moët-Hennessy } \\
\text { company with the } \\
\text { Louis Vuitton leather } \\
\text { merchandiser, and } \\
\text { integration of the } \\
\text { Ruinart, Mercier and } \\
\text { Krug brands. } \\
\text { The acronym LVMH } \\
\text { includes the initials of } \\
\text { the Louis Vuitton } \\
\text { groups and the Maison } \\
\text { Moët-Hennessy }\end{array}$ & $\begin{array}{l}\text { 1987: the brand } \\
\text { and family } \\
\text { history are } \\
\text { integrated into } \\
\text { the LVMH group }\end{array}$ & $\begin{array}{l}\text { 1987: } \\
\text { integration } \\
\text { with the } \\
\text { LVMH group }\end{array}$ & $\begin{array}{l}\text { 1987: } \\
\text { integration with } \\
\text { the LVMH group }\end{array}$ & $\begin{array}{l}\text { 1987: } \\
\text { integration } \\
\text { with the } \\
\text { LVMH } \\
\text { group }\end{array}$ \\
\hline
\end{tabular}

